\title{
SODIUM PHYTOREMEDIATION BY GREEN MANURE GROWING IN SOIL IRRIGATED WITH WASTEWATER OF DAIRY INDUSTRY
}

Doi:http://dx.doi.org/10.1590/1809-4430-Eng.Agric.v37n4p665-675/2017

\section{RAMON N. DONATTI ${ }^{1}$, TAMARA M. GOMES ${ }^{2}$, LUANA C. MENEGASSI ${ }^{2}$, GIOVANA TOMMASO ${ }^{2}$, FABRÍCIO ROSSI ${ }^{3 *}$}

\author{
${ }^{3 *}$ Corresponding author. University of São Paulo - Faculty of Animal Science and Food Engineering/ Pirassununga - SP, \\ Brasil.E-mail: fabricio.rossi@usp.br
}

\begin{abstract}
Phytoremediation is a technique that uses plants to decontaminate soils containing harmful organic and inorganic elements. The aim of this study was to evaluate the potential of three species of forage green manure in phytoremediation of saline soil irrigated with treated effluent from dairy processing plant. The design used was randomized blocks $(3 \times 3)$ with four replicates. The treatments were three different water sources (anaerobic treated effluent, aerobic treated effluent, and tap water) applied to growing table beets combined with the post-cultivation of three forage green manure: Calopogonium mucunoides Desv (Calopo), Cajanus cajan (L.) Millsp (Pigeon pea), and Pennisetum glaucum (L.) R. Brown (Millet). The treatment with Millet had higher dry mass production with all water sources, although showing growth reduction after irrigation with anaerobic treated effluent. Millet presented higher sodium extraction efficiency $\left(22.4 \mathrm{~kg} \mathrm{ha}^{-1}\right)$; however, it was not effective in soil phytoremediation because the exchangeable sodium percentage was not reduced to levels that allowed for new effluent input.
\end{abstract}

KEYWORDS: reuse water, phytoextraction, salinization.

\section{INTRODUCTION}

The dairy industries are of the utmost importance, since they are directly and indirectly responsible in the food chain in Brazil. According to Mendonça et al. (2015) the volumes of effluents generate by a small dairy plant, processing up to 10 thousand liters of milk per day can be three times the volume of processed milk. Azzolini \& Fabro (2013) highlight the high organic load present in the effluents generated by dairy plants and its high polluting potential. For the effective treatment of such effluent, the dairy industry must know its characteristics and aspects of treatability, and designing proper units (Sutar et al., 2015).

The proper treatment of effluents from dairy plants is required for its discharge within the legal standards (Brasil, 2005), without impacting drastically the water resources. Nonetheless, the removal of nitrogen and phosphorus to meet the release standards is inefficient in biological processes, representing large costs for treatment plants. The discharge of these elements into water bodies causes serious problems of eutrophication (Gomes et al., 2015). An option for the discharge of treated effluents in water courses is its reuse in agriculture. The main advantage in reusing treated effluents in agriculture is the water exploitation for irrigation purposes and the integration of activities (industrial and agricultural), avoiding fresh water to be collected from rivers or reservoirs (Rossi et al., 2014).

Depending on the product, milk processing may add high concentrations of sodium to dairy effluents. Such compound is recalcitrant to biological treatments, remaining unaffected after the processes. Irrigation with high concentrations of sodium causes salinization and physical-chemical alterations to the soil, such as increase in the osmotic potential of the water and reduction in water infiltration in the soil, resulting in significant losses in crop yield (Ayers \& Westcot, 1999). Intending to solve problems related to salinization and sodification, in order to make irrigation with treated effluents feasible, Phytoremediation is an alternative.

\footnotetext{
${ }^{1}$ University of São Carlos/ Araras - SP, Brasil.

${ }^{2}$ University of São Paulo - Faculty of Animal Science and Food Engineering/ Pirassununga - SP, Brasil. 
The selection of potential phytoremediation agents is still a complex issue due to the small number of developed studies. According to Santos et al., (2014) some legumes (family Fabaceae), as Crotalaria juncea and Crotalaria spectabilis, present resistance to high salinity levels for certain period of time. The legumes, in symbiotic association to bacteria, also contribute to the biological nitrogen fixation. In other hand, the family Poaceae, due to its high level of phytomass development, can decompress and structure the soil, contributing to phytoextraction.

In a sustainable model the integration among agricultural activities becomes fundamental: the milk produced by the lactating cows is processed in the dairy plant, where the effluents are generated needing treatment for their disposal; these treated effluents can be used in the irrigation of commercial crops, but may cause soil salinization and sodification. Phytoremediation can make the soil proper to receive new cycles of wastewater irrigation; finally, when the phytoremediation species are fodder, they can feed dairy cattle, closing a productive cycle.

With the aim of promoting new accessible technologies and contributing to the reuse and treatment of wastewater, this study aimed to evaluate the potential of three species of forage green manure: Calopo (Calopogonium mucunoides Desv); Pigeon pea (Cajanus cajan (L.) Millsp) and Millet (Pennisetum glaucum (L.) R. Brown) in the phytoremediation of saline soil previously irrigated with dairy wastewaters.

\section{MATERIAL AND METHODS}

The experiment was conducted in a $210 \mathrm{~m}^{2}$ greenhouse located at the Biosystems Engineering Department of the Faculty of Animal Science and Food Engineering (FZEA/USP). At altitude of $627 \mathrm{~m}$, latitude $21^{\circ} 59^{\prime} \mathrm{S}$ and longitude $47^{\circ} 25^{\prime} \mathrm{W}$, the climate of the region is considered to be the Cwa type in the classification of Koppen (Koppen, 1931), with average annual temperature of 20.8 ${ }^{\circ} \mathrm{C}$ and with average rainfall $1089 \mathrm{~mm}$ per year.

The experimental blocks were boxes with $0.5 \mathrm{~m}^{3}$, with $1 \mathrm{~m}^{2}$ of surface area. The experimental design used randomized blocks in a factorial scheme $(3 \times 3)$ with 4 replicates. The treatments were composed by three sources of water used for table beet cultivation (anaerobic effluent - ANE; aerobic effluent - AE; and tap water - TW), combined with three forage fertilizers (Chart 1). TW was used for the forage fertilizers cultivation.

CHART 1. Culture cycle, water source and irrigation depth, which defined the factorial design of the randomized block design, with nine treatments.

\begin{tabular}{|c|c|c|c|c|c|c|}
\hline & \multicolumn{2}{|c|}{$1^{\circ}$ cycle: table beets } & & \multicolumn{3}{|c|}{$2^{\circ}$ cycle: green manure } \\
\hline Treatments & Water Source & Irrigation Depth & & Specie & Water Source & Irrigation Depth \\
\hline 1 & $\mathrm{AE}$ & $50 \% \mathrm{ET}_{\mathrm{C}}$ & $\rightarrow$ & Calopo & TW & $100 \% \mathrm{ET}_{\mathrm{C}}$ \\
\hline 2 & $\mathrm{AE}$ & $100 \% \mathrm{ET}_{\mathrm{C}}$ & $\rightarrow$ & Pigeon pea & TW & $100 \% \mathrm{ET}_{\mathrm{C}}$ \\
\hline 3 & $\mathrm{AE}$ & $150 \% \mathrm{ET}_{\mathrm{C}}$ & $\rightarrow$ & Millet & TW & $100 \% \mathrm{ET}_{\mathrm{C}}$ \\
\hline 4 & ANE & $50 \% \mathrm{ET}_{\mathrm{C}}$ & $\rightarrow$ & Calopo & TW & $100 \% \mathrm{ET}_{\mathrm{C}}$ \\
\hline 5 & ANE & $100 \% \mathrm{ET}_{\mathrm{C}}$ & $\rightarrow$ & Pigeon pea & TW & $100 \% \mathrm{ET}_{\mathrm{C}}$ \\
\hline 6 & ANE & $150 \% \mathrm{ET}_{\mathrm{C}}$ & $\rightarrow$ & Millet & TW & $100 \% \mathrm{ET}_{\mathrm{C}}$ \\
\hline 7 & $\mathrm{TW}$ & $50 \% \mathrm{ET}_{\mathrm{C}}$ & $\rightarrow$ & Calopo & TW & $100 \% \mathrm{ET}_{\mathrm{C}}$ \\
\hline 8 & TW & $100 \% \mathrm{ET}_{\mathrm{C}}$ & $\rightarrow$ & Pigeon pea & TW & $100 \% \mathrm{ET}_{\mathrm{C}}$ \\
\hline 9 & TW & $150 \% \mathrm{ET}_{\mathrm{C}}$ & $\rightarrow$ & Millet & TW & $100 \% \mathrm{ET}_{\mathrm{C}}$ \\
\hline
\end{tabular}

ANE: anaerobic effluent; AE: aerobic effluent; TW: tap water; ETc: crop evapotranspiration.

Table 1 shows the chemical characteristics of the water sources used in the irrigation of the table beet that was cultivated previously to the green fertilizers, leaving residual for the later cultivation of the green fertilizers. 
It is worth noting that the values of the Sodium Adsorption Ratio (SAR) for both types of effluent (AE and ANE) are below the maximum value recommended by CETESB (2006), when such value is correlated with the electrical conductivity value (EC), nevertheless, the presented values of sodium and chloride are superior to $69 \mathrm{mg} \mathrm{L}^{-1}$ and $109 \mathrm{mg} \mathrm{L}^{-1}$, respectively, therefore above the recommended values.

The main nutrient present in treated dairy effluents is nitrogen $(\mathrm{N})$, but there is also phosphorus $(\mathrm{P})$, potassium $(\mathrm{K})$, calcium $(\mathrm{Ca})$ and magnesium $(\mathrm{Mg})$. Due to the higher nutrients uptake in such process, in general, the effluent from the aerobic reactor presents lower nutrients concentrations when compared to the anaerobic treated effluent (Table 1).

The concentration of $\mathrm{N}-\mathrm{NH}_{4}^{+}$is higher in ANE compared to AE, as a result of the anaerobic decomposition of nitrogen organic matter, while in the aerobic reactor, the presence of oxygen allows the transformation of the ammonium ion $\left(\mathrm{N}-\mathrm{NH} 4^{+}\right)$into Nitrite $\left(\mathrm{N}-\mathrm{NO}^{2-}\right)$ and nitrate $(\mathrm{N}-$ $\left.\mathrm{NO}^{3-}\right)$, which consequently presented higher values in AE in relation to ANE.

TABLE 1. Evaluated parameters (N, P, K, Ca, Mg, Na, Cl, SAR, CE and pH) of anaerobic effluent (ANE), aerobic effluent (AE) of dairy and tap water (TW). University of São Paulo, Animal Science and Food Engineering, (FZEA/USP), Pirassununga, 2014.

\begin{tabular}{|c|c|c|c|}
\hline Parameter & $\frac{\text { ANE }}{\text { After ultraviolet }}$ & $\mathrm{AE}$ & -TW \\
\hline NTK-N (mg L-1) & $89.69 \pm 35.25$ & $49.89 \pm 35.01$ & $19.46 \pm 2.47$ \\
\hline $\mathrm{NH}_{4}{ }^{+}-\mathrm{N}\left(\mathrm{mg} \mathrm{L}^{-1}\right)$ & $51.24 \pm 31.11$ & $22.16 \pm 25.73$ & $0.00 \pm 0.00$ \\
\hline $\mathrm{NO}_{3}-\mathrm{N}\left(\mathrm{mg} \mathrm{L}^{-1}\right)$ & $0.71 \pm 0.75$ & $15.24 \pm 24.34$ & $0.26 \pm 0.05$ \\
\hline $\mathrm{NO}_{2}{ }^{-}-\mathrm{N}\left(\mathrm{mg} \mathrm{L}^{-1}\right)$ & $0.05 \pm 0.05$ & $0.90 \pm 1.24$ & $0.00 \pm 0.00$ \\
\hline Total $\mathrm{P}\left(\mathrm{mg} \mathrm{L}^{-1}\right)$ & $5.70 \pm 1.78$ & $4.47 \pm 1.87$ & $0.21 \pm 0.17$ \\
\hline Soluble $\mathrm{P}\left(\mathrm{mg} \mathrm{L}^{-1}\right)$ & $4.49 \pm 1.60$ & $3.65 \pm 1.55$ & $0.05 \pm 0.03$ \\
\hline $\mathrm{K}^{+}\left(\mathrm{mg} \mathrm{L}^{-1}\right)$ & $59.67 \pm 17.56$ & $54.17 \pm 26.57$ & $0.23 \pm 0.05$ \\
\hline $\mathrm{Ca}^{+2}\left(\mathrm{mg} \mathrm{L}^{-1}\right)$ & $54.41 \pm 20.26$ & $67.05 \pm 17.46$ & $6.85 \pm 1.06$ \\
\hline $\mathrm{Mg}^{+2}\left(\mathrm{mg} \mathrm{L}^{-1}\right)$ & $86.16 \pm 7.22$ & $65.83 \pm 16.42$ & $1.83 \pm 0.27$ \\
\hline $\mathrm{Na}^{+}\left(\mathrm{mg} \mathrm{L}^{-1}\right)$ & $366.83 \pm 111.22$ & $318.83 \pm 133.63$ & $1.78 \pm 0.65$ \\
\hline $\mathrm{Cl}^{-}\left(\mathrm{mg} \mathrm{L}^{-1}\right)$ & $171.32 \pm 60.22$ & $149.22 \pm 57.74$ & $2.39 \pm 1.98$ \\
\hline $\mathrm{SAR}(\mathrm{mmol} / \mathrm{L})^{-1 / 2}$ & $7.28 \pm 2.44$ & $6.66 \pm 2.76$ & $0.16 \pm 0.05$ \\
\hline $\mathrm{EC}\left(\mathrm{dS} \mathrm{m}^{-1}\right)$ & $3.53 \pm 1.35$ & $2.43 \pm 0.80$ & $0.04 \pm 0.02$ \\
\hline $\mathrm{pH}$ & $8.03 \pm 0.35$ & $8.28 \pm 0.20$ & $6.92 \pm 0.18$ \\
\hline
\end{tabular}

$\mathrm{TW}=$ Tap water; $\mathrm{AE}=$ Aerobic effluent; $\mathrm{ANE}=$ Anaerobic effluent; $\mathrm{TKN}=$ Total Kjeldahl Nitrogen, $\mathrm{SAR}=$ sodium adsorption ratio; $\mathrm{EC}=$ Electrical Conductivity.

$3 \mathrm{~g} \mathrm{~m}^{-2}$ of Millet seeds, $6 \mathrm{~g} \mathrm{~m}^{-2}$ of Calopo seeds and $12 \mathrm{~g} \mathrm{~m}^{-2}$ of Pigeon pea were used for the Green manure seeding, having being uniformly disposed in 12 lines in the plots.

The soil, sampled from 0-30 cm, presented the chemical characteristics described in Table 2, residual result of fertilization and the application of water sources during table beet cultivation.

No fertilization was done for the cultivation of green forage fertilizers, except for the application of $100 \mathrm{~kg} \mathrm{ha}^{-1}$ of nitrogen (N) in the plots with Millet, divided in four times at 30, 40,50 and 60 days after emergence (DAE). This supply of $\mathrm{N}$ is justified because the millet crop is a grass and is not benefited by the biological nitrogen fixation (BNF), as it happens with the Fabaceae family (Calopo and Pigeon pea). 
TABLE 2. Soil chemical analysis before cultivation $(0-30 \mathrm{~cm})$ of green manure and after table beet cultivation. University of São Paulo, Animal Science and Food Engineering (FZEA/USP), Pirassununga, 2014.

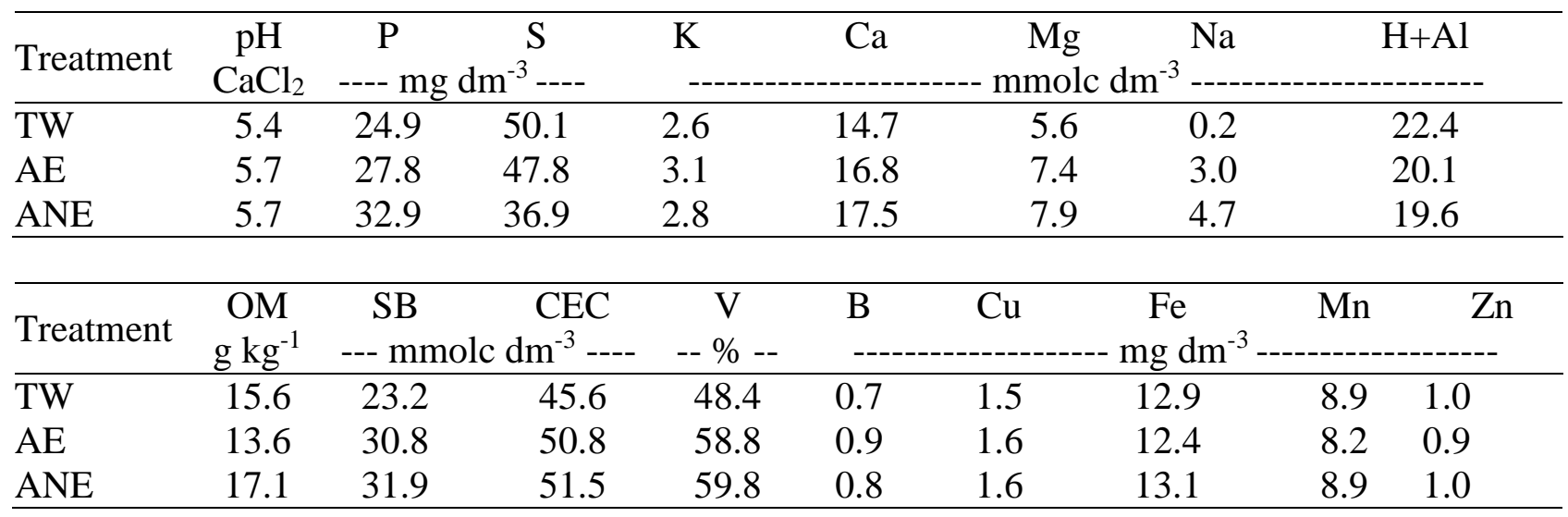

TW=Tap water; $\mathrm{AE}=$ Aerobic effluent; $\mathrm{ANE}=$ Anaerobic effluent.

Extractors: P, K, Ca and Mg (resin); S (Calcium phosphate); B (hot water); micro (DPTA)

A drip system with emitters of flow rate $2.4 \mathrm{~L} \mathrm{~h}^{-1}$, spaced $20 \mathrm{~cm}$ apart, was used for the conduction of the irrigation. One irrigation line was set for every two cultivation rows. The irrigation shift was set in two days. Irrigation management was based on the replacement of estimated crop evapotranspiration (ETc), calculated using a reduced Class A evaporation pan installed on a $0.15 \mathrm{~m}$ high wooden platform in the central part of the green house. The Etc measured was multiplied by the coefficient of culture $(\mathrm{Kc})$ in its different stages, as proposed by Food and Agriculture Organization of the United Nations (FAO, 2008). The correction coefficient used for the reduced pan inside the greenhouse was 1, as recommended by Prados (1986) and cited by Farias et al. (1994).

The maximum and minimum air humidity and temperature values were monitored by daily reading of the digital thermohygrometer located in the central area of the greenhouse. The values observed did not influence the development of the green manures. The maximum relative humidity was $84 \%$ and the minimum relative humidity was $20 \%$, while $48.4{ }^{\circ} \mathrm{C}$ was the maximum temperature and $11.8^{\circ} \mathrm{C}$ the minimum.

The green manures were managed within 85 days of development. The plants were cut into the ground, separated into above-ground parts and roots, and both were washed with water followed by $0.1 \%$ hydrochloric acid solution, for the removal of impurities. Then, both the shoot and the roots were dried in a forced circulation oven at $65{ }^{\circ} \mathrm{C}$ for 72 hours. Later they were weighed for determination of dry mass, ground in a Willey mill, and sent for nutritional diagnosis analysis made by Laboratory of Agricultural Sciences/FZEA Soils/USP, following the methods described by Malavolta et al. (1997).

Soil samples collected three depths: $0-10 \mathrm{~cm}, 10-20 \mathrm{~cm}$ and $20-30 \mathrm{~cm}$, were analyzed by the resin extraction method (Raij et al., 2001), in the Laboratory of Agricultural Sciences/FZEA Soils/USP. The exchangeable sodium percentage (ESP) was calculated considering the exchangeable sodium ratio in the cation exchange capacity (CEC). According to methodology proposed by EMBRAPA (1997), the soil was processed in saturation pulps to obtain aqueous extract of the soil, in order to determine calcium, sodium and magnesium ions for subsequent calculation of SAR by the equation described by Ayers \& Westcot (1999). The data were subjected to variance analysis. For situations in which there were significant differences, means were compared by the Tukey test with a $5 \%$ significance level $(\mathrm{p}<0.05)$ by SISVAR 5.3 software (Ferreira, 2011). To meet the assumptions of the analysis of variance, the phytoextraction data were transformed into $\sqrt{\mathrm{x}}$. 


\section{RESULTS AND DISCUSSION}

The results concerning the shoot dry mass (SDM) productivity of the green manures are presented in Table 3. Millet showed higher production of SDM after irrigation with tap water (TW), when compared to Calopo and Pigeon pea. It was also observed higher productivity of the Millet compared to Pigeon pea when the AE was used in the irrigation, although in this treatment, the millet showed no productivity difference in relation to Calopo. In the treatment using ANE there was no difference among the used green manures for SDM.

TABLE 3. Shoot dry mass (SDM) of green manures (Calopo, Pigeon pea, Millet) cultivated in succession to irrigation with different water sources (tap water - TW, anaerobic effluent - ANE, aerobic effluent - AE). University of São Paulo, Animal Science and Food Engineering, 2014.

\begin{tabular}{lcccc}
\hline Green manures & TW & ANE & AE & Reference* \\
& --- - $^{*}$ & $---\mathrm{kg} \mathrm{m}^{-2}----$ \\
\hline Calopo & $0.40 \mathrm{Ab}$ & $0.57 \mathrm{Aa}$ & $0.66 \mathrm{Aab}$ & $0.4-0.5$ \\
Pigeon pea & $0.60 \mathrm{Ab}$ & $0.56 \mathrm{Aa}$ & $0.50 \mathrm{Ab}$ & $0.3-0.7$ \\
Millet & $1.12 \mathrm{Aa}$ & $0.77 \mathrm{Ba}$ & $0.89 \mathrm{ABa}$ & $0.6-1.5$ \\
\hline
\end{tabular}

V.C. $(\%)$ 26,81

*Expected yield of green manure in the ideal crop cycle (Adapted by Calegari \& Carlos, 2014).

Equivalent upper or lower case letters in rows and columns, respectively, do not differ statistically by the Tukey test $(p<0.05)$.

Calopo and Pigeon pea presented similar productivities for SDM in relation to all water sources, although Calopo presented more than 50\% of SDM increase with TW compared to AE, which did not result in statistical difference.

Millet presented reduction of SDM productivity in ANE in relation to TW, possibly due to the higher soil salinity (Table 3).

Comparing the SDM productivity results with ideal crop cycle $\left(0.4-0.5 \mathrm{~kg} \mathrm{~m}^{-2}\right.$ according to Calegari \& Carlos et al., (2014)), it is possible to verify that Calopo present slight higher values for treatments $\operatorname{ANE}\left(0.57 \mathrm{~kg} \mathrm{~m}^{-2}\right)$ and $\operatorname{AE}\left(0.66 \mathrm{~kg} \mathrm{~m}^{-2}\right)$, considering that the vegetative cycle for such forager is 240 days, while it was cultivated for 85 days in the present research. Millet and Pigeon pea had expected SDM values when compared to ideal crop cycle.

In a similar experiment, Rossi et al. (2014) obtained SDM productivity of $0.38 \mathrm{~kg} \mathrm{~m}^{-2}$ of for Millet irrigated with anaerobic treated dairy effluent. The authors attributed the lower productivity to the non-delivery of the nitrogen to the millet, which could be verified by the yellowing and the indirect measurement of chlorophyll in the leaves.

Table 4 presents data on the variation of the root dry mass (RDM) of green manures. Millet presented the highest values of RDM in all treatments, differing from Calopo and Pigeon pea. Analyzing each green manure separately, it is possible to observe that the water sources did no influence in RDM production, inferring that there was no influence of the salinity on the roots development.

TABLE 4. Root dry mass (RDM) of green manures (Calopo, Pigeon pea, Millet) cultivated in succession to irrigation with different water sources (tap water - TW, anaerobic effluent - ANE, aerobic effluent - AE). University of São Paulo, Animal Science and Food Engineering, 2014.

\begin{tabular}{lccc}
\hline Green manures & TW & ANE & AE \\
\hline Calopo & & $-0.021 \mathrm{Ab}$ & $0.037 \mathrm{Ab}$ \\
Pigeon pea & $0.053 \mathrm{Ab}$ & $0.039 \mathrm{Ab}$ & $0.038 \mathrm{Ab}$ \\
Millet & $0.054 \mathrm{Ab}$ & $0.093 \mathrm{Aa}$ & $0.083 \mathrm{Aa}$ \\
\hline V.C. $(\%)$ & $0.124 \mathrm{Aa}$ & 43.43 & \\
\hline
\end{tabular}

Equivalent upper or lower case letters in rows and columns, respectively, do not differ statistically by the Tukey test (p<0.05). 
Table 5 presents the main values of the macronutrients phytoextration carried out by the green manures. The values observed for Nitrogen $(\mathrm{N})$, potassium $(\mathrm{K})$, calcium $(\mathrm{Ca})$, Magnesium $(\mathrm{Mg})$ and sulfur (S) did not show interaction among the sources of water and the green manures. The Nitrogen phytoextration was in average $124 \mathrm{~kg} \mathrm{ha}^{-1}$, being similar with all used green manure in all treatments. The same behavior was verified for $\mathrm{Ca}, \mathrm{Mg}$ and $\mathrm{S}$, which phytoextraction were in average $17.8 \mathrm{~kg} \mathrm{ha}^{-1}, 6.6 \mathrm{~kg} \mathrm{ha}^{-1}$ and $13.9 \mathrm{~kg} \mathrm{ha}^{-1}$, respectively. Millet extracted the higher quantity of Calcium (in average $214.6 \mathrm{~kg} \mathrm{ha}^{-1}$ ), with all water sources, statistically differing from Calopo $\left(96.8 \mathrm{~kg} \mathrm{ha}^{-1}\right)$ and Pigeon pea $\left(71.1 \mathrm{~kg} \mathrm{ha}^{-1}\right)$.

TABLE 5. Phytoextraction of macronutrients by shoot of green manures (Calopo, Pigeon pea, Millet) cultivated in succession to irrigation with different water sources (Tap water TW, anaerobic effluent - ANE, aerobic effluent - AE). University of São Paulo, Animal Science and Food Engineering, 2014.

\begin{tabular}{|c|c|c|c|c|}
\hline \multirow{2}{*}{ Green manures } & TW & $\mathrm{AE}$ & ANE & Mean \\
\hline & \multicolumn{4}{|c|}{$\mathrm{N}\left(\mathrm{kg} \mathrm{ha}^{-1}\right)$} \\
\hline Calopo & 99.6 & 177.1 & 142.3 & $139.6 \mathrm{a}$ \\
\hline Pigeon pea & 147.1 & 113.6 & 129.4 & $130.0 \mathrm{a}$ \\
\hline Millet & 107.5 & 97.8 & 101.1 & $102.1 \mathrm{a}$ \\
\hline Mean & $118.1 \mathrm{~A}$ & $129.5 \mathrm{~A}$ & $124.3 \mathrm{~A}$ & \\
\hline \multirow[t]{2}{*}{ V.C. $(\%)$} & \multicolumn{3}{|c|}{18.14} & \\
\hline & \multicolumn{3}{|c|}{$\mathrm{P}\left(\mathrm{kg} \mathrm{ha}^{-1}\right)$} & \\
\hline Calopo & $3.2 \mathrm{Bb}$ & $10.9 \mathrm{Aa}$ & $10.5 \mathrm{Aa}$ & 8.2 \\
\hline Pigeon pea & $4.4 \mathrm{Ab}$ & $3.9 \mathrm{Ab}$ & $4.0 \mathrm{Ab}$ & 4.1 \\
\hline Millet & $10.4 \mathrm{Aa}$ & 8.3Aab & $6.1 \mathrm{Aab}$ & 8.3 \\
\hline Mean & 6.0 & 7.7 & 6.9 & \\
\hline \multirow[t]{2}{*}{ V.C. $(\%)$} & \multicolumn{3}{|c|}{23.78} & \\
\hline & \multicolumn{3}{|c|}{$\mathrm{K}\left(\mathrm{kg} \mathrm{ha}^{-1}\right)$} & \\
\hline Calopo & 47.1 & 135.9 & 107.4 & $96.8 b$ \\
\hline Pigeon pea & 66.2 & 71.6 & 75.5 & $71.1 \mathrm{~b}$ \\
\hline Millet & 217.3 & 234.1 & 192.2 & $214.6 \mathrm{a}$ \\
\hline Mean & $110.2 \mathrm{~A}$ & $147.2 \mathrm{~A}$ & $125.1 \mathrm{~A}$ & \\
\hline \multirow[t]{2}{*}{ V.C. $(\%)$} & \multicolumn{3}{|c|}{14.13} & \\
\hline & \multicolumn{3}{|c|}{$\mathrm{Ca}\left(\mathrm{kg} \mathrm{ha}^{-1}\right)$} & \\
\hline Calopo & 11.8 & 17.2 & 15.9 & $15.0 \mathrm{a}$ \\
\hline Pigeon pea & 19.4 & 17.7 & 18.0 & $18.4 \mathrm{a}$ \\
\hline Millet & 25.0 & 18.4 & 16.9 & $20.1 \mathrm{a}$ \\
\hline Mean & $18.8 \mathrm{~A}$ & $17.8 \mathrm{~A}$ & $17.0 \mathrm{~A}$ & \\
\hline \multirow[t]{2}{*}{ V.C. $(\%)$} & \multicolumn{3}{|c|}{27.34} & \\
\hline & \multicolumn{3}{|c|}{$\operatorname{Mg}\left(\mathrm{kg} \mathrm{ha}^{-1}\right)$} & \\
\hline Calopo & 4.4 & 5.5 & 7.3 & $5.7 \mathrm{a}$ \\
\hline Pigeon pea & 8.3 & 4.5 & 5.7 & $6.2 \mathrm{a}$ \\
\hline Millet & 9.7 & 6.0 & 7.8 & $7.8 \mathrm{a}$ \\
\hline Mean & $7.5 \mathrm{~A}$ & $5.3 \mathrm{~A}$ & $6.9 \mathrm{~A}$ & \\
\hline \multirow[t]{2}{*}{ V.C. $(\%)$} & \multicolumn{3}{|c|}{21.38} & \\
\hline & \multicolumn{3}{|c|}{$\mathrm{S}\left(\mathrm{kg} \mathrm{ha}^{-1}\right)$} & \\
\hline Calopo & 4.8 & 11.5 & 43.6 & $20.0 \mathrm{a}$ \\
\hline Pigeon pea & 7.9 & 6.9 & 8.3 & $7.7 \mathrm{a}$ \\
\hline Millet & 16.0 & 15.3 & 10.4 & $13.9 \mathrm{a}$ \\
\hline Mean & $9.6 \mathrm{~A}$ & $11.2 \mathrm{~A}$ & $20.8 \mathrm{~A}$ & \\
\hline V.C. $(\%)$ & & 47.46 & & \\
\hline
\end{tabular}

Equivalent upper or lower case letters in rows and columns, respectively, do not differ statistically by the Tukey test (p <0.05). 
The P phytoextraction happened occurred differently for the green manure, using the three different source of water. It was possible to observe that Calopo phytoextracts higher amounts of $\mathrm{P}$ when cultivated in soil irrigated with both treatment effluents (AE and ANE), while Pigeon pea and millet did not show the same characteristic (Table 5).

Millet phytoextracted $22.4 \mathrm{~kg} \mathrm{ha}^{-1}$ of $\mathrm{Na}$, statistically differing from Pigeon pea $\left(11.4 \mathrm{~kg} \mathrm{ha}^{-1}\right)$, considering average values obtained with all different water sources (Figure 1). Millet cultivated in soil previously irrigated with anaerobically treated effluent phytoextracted $29.3 \mathrm{~kg} \mathrm{ha}^{-1}$ of $\mathrm{Na}$, but without statistical difference for the other used water sources. This fact may be related to the smaller production of shoot dry mass obtained for Millet in the cultivated after ANE $\left(0.77 \mathrm{~kg} \mathrm{~m}^{-2}\right)$ and EA $\left(0.89 \mathrm{~kg} \mathrm{~m}^{-2}\right)$, when compared to TW $\left(1.12 \mathrm{~kg} \mathrm{~m}^{-2}\right)$, which means 31 and $20 \%$ less of SDM respectively (Table 3). Rossi et al., (2014) reported the phytoextraction of $14.69 \mathrm{~kg}$ of Na ha ${ }^{-1}$ by Millet in post-cultivation of table beet irrigated with anaerobically dairy treated effluent.

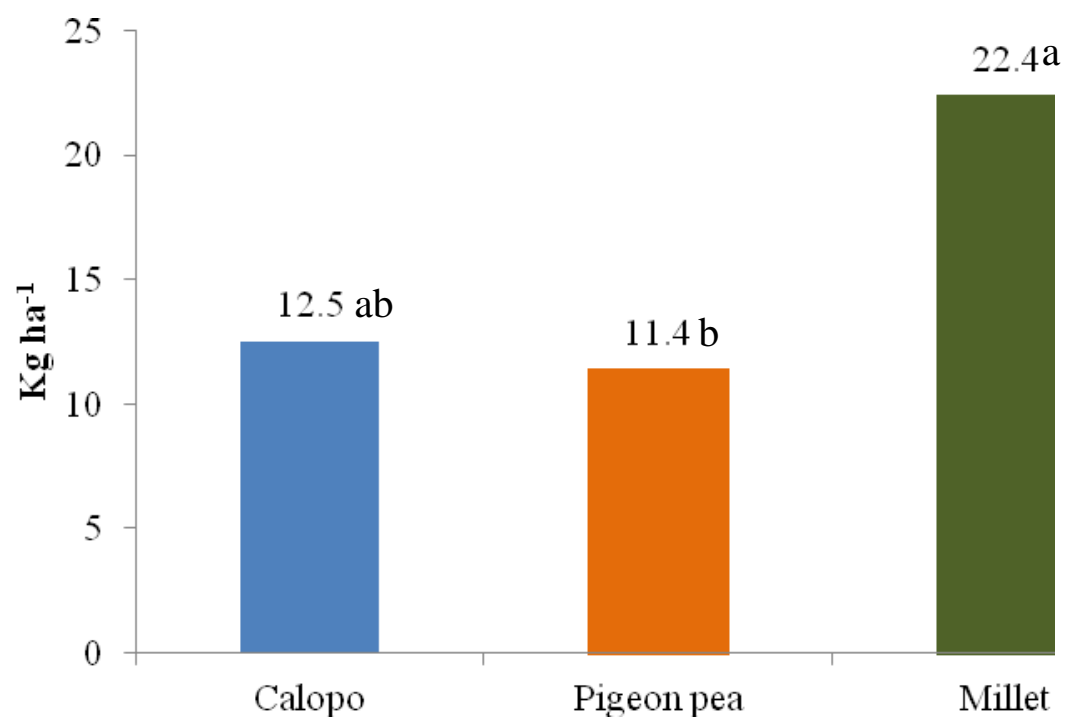

FIGURE 1. Sodium phytoextraction by shoot of green manures (Calopo, Pigeon pea, Millet) cultivated in succession to irrigation with different water sources (tap water - TW, anaerobic effluent - ANE, aerobic effluent - AE). University of São Paulo, Animal Science and Food Engineering, 2014. Means followed by distinct letters differ from one another by the Tukey test $(\mathrm{p}<0.05)$.

In relation to the micronutrient phytoextraction, Boron $(\mathrm{B})$ and Cupper $(\mathrm{Cu})$ did not show differences among the treatments, presenting average extraction of $9.07 \mathrm{~g} \mathrm{ha}^{-1}$ and $932.16 \mathrm{~g} \mathrm{ha}^{-1}$, respectively (Table 6). $\mathrm{Cu}$, independently of the water source, was phytoextracted in higher amounts by Calopo (203.7 $\mathrm{g} \mathrm{ha}^{-1}$ ) in relation to the other green manures. This fact may be explained by the applications of Bordeaux mixture for Powdery mildew (fungal disease present in Calopo) control. The other studied elements, manganese $(\mathrm{Mn})$ and zinc $(\mathrm{Zn})$, varied according to green manures and water sources. Millet was the green manure that promoted the highest phytoestraction of $\mathrm{Mn}$, when TW was used (406.8 $\left.\mathrm{g} \mathrm{ha}^{-1}\right)$, being superior to Calopo $\left(99.9 \mathrm{~g} \mathrm{ha}^{-1}\right)$, and both not differing from Pigeon pea $\left(271.8 \mathrm{~g} \mathrm{ha}^{-1}\right)$. Nevertheless, such difference did not occur when the other water sources were used. The Mn phytoextraction by Millet varied according to the used water source, being higher to TW (406.8 $\left.\mathrm{g} \mathrm{ha}^{-1}\right)$, but decreasing in the cultivation after AE (212.7 $\mathrm{g} \mathrm{ha}^{-1}$ ) and ANE (159.4 $\mathrm{g} \mathrm{ha}^{-1}$ ). In relation to $\mathrm{Zn}$, Calopo and Pigeon pea did not show differences among the water sources. Millet, on the other hand, reduced the extraction after cultivation in ANE (28.4 $\left.\mathrm{g} \mathrm{ha}^{-1}\right)$, when compared to TW (48.1 $\left.\mathrm{g} \mathrm{ha}^{-1}\right)$. However, except for the treatment 4, ANE, Millet presented the higher phytoextraction in comparison to Calopo and Pigeon pea for TW and AE (Table 5). 
TABLE 6. Phytoextraction of micronutrients by shoot of green manures (Calopo, Pigeon pea, Millet) cultivated in succession to irrigation with different water sources (tap water TW, anaerobic effluent - ANE, aerobic effluent - AE). University of São Paulo, Animal Science and Food Engineering, 2014.

\begin{tabular}{|c|c|c|c|c|}
\hline Green manures & TW & $\mathrm{AE}$ & ANE & Mean \\
\hline & \multicolumn{4}{|c|}{$\mathrm{B}\left(\mathrm{g} \mathrm{ha}^{-1}\right)$} \\
\hline Calopo & 6.7 & 12.9 & 5.6 & $8.4 \mathrm{a}$ \\
\hline Pigeon pea & 6.1 & 7.7 & 10.0 & $8.0 \mathrm{a}$ \\
\hline Millet & 12.5 & 10.1 & 9.8 & $10.8 \mathrm{a}$ \\
\hline Mean & $8.5 \mathrm{~A}$ & $10.2 \mathrm{~A}$ & $8.5 \mathrm{~A}$ & \\
\hline \multirow[t]{2}{*}{ V.C. $(\%)$} & \multicolumn{4}{|c|}{31.22} \\
\hline & \multicolumn{4}{|c|}{$\mathrm{Cu}\left(\mathrm{g} \mathrm{ha}^{-1}\right)$} \\
\hline Calopo & 201.7 & 242.2 & 167.1 & $203.7 \mathrm{a}$ \\
\hline Pigeon pea & 33.4 & 37.6 & 47.2 & $39.4 b$ \\
\hline Millet & 107.2 & 49.3 & 55.8 & $70.8 b$ \\
\hline Mean & $114.1 \mathrm{~A}$ & $109.7 \mathrm{~A}$ & $90.0 \mathrm{~A}$ & \\
\hline \multirow[t]{2}{*}{ V.C. $(\%)$} & \multicolumn{4}{|c|}{39.24} \\
\hline & \multicolumn{4}{|c|}{$\mathrm{Fe}\left(\mathrm{g} \mathrm{ha}^{-1}\right)$} \\
\hline Calopo & 739.6 & 1243.4 & 1105.5 & $1029.5 a$ \\
\hline Pigeon pea & 853.6 & 687.7 & 757.5 & $766.2 \mathrm{a}$ \\
\hline Millet & 1151.2 & 934.9 & 916.4 & $1000.8 \mathrm{a}$ \\
\hline Mean & 914.8A & $955.3 \mathrm{~A}$ & $926.4 \mathrm{~A}$ & \\
\hline \multirow[t]{2}{*}{ V.C. $(\%)$} & \multicolumn{4}{|c|}{26.73} \\
\hline & \multicolumn{4}{|c|}{$\operatorname{Mn}\left(\mathrm{g} \mathrm{ha}^{-1}\right)$} \\
\hline Calopo & $99.9 \mathrm{Ab}$ & 174.0Aa & 161.0Aa & 145.0 \\
\hline Pigeon pea & 271.8Aab & 206.9Aa & $270.7 \mathrm{Aa}$ & 249.5 \\
\hline Millet & 406.8Aa & $212.7 \mathrm{Ba}$ & $159.4 \mathrm{Ba}$ & 259.7 \\
\hline Mean & 259.5 & 197.6 & 197.0 & \\
\hline \multirow[t]{2}{*}{ V.C. $(\%)$} & \multicolumn{4}{|c|}{26.62} \\
\hline & \multicolumn{4}{|c|}{$\mathrm{Zn}\left(\mathrm{g} \mathrm{ha}^{-1}\right)$} \\
\hline Calopo & $17.0 \mathrm{Ab}$ & $28.9 \mathrm{Ab}$ & $22.4 \mathrm{Aa}$ & 22.7 \\
\hline Pigeon pea & $21.9 \mathrm{Ab}$ & 19.8Aab & 20.9Aa & 20.8 \\
\hline Millet & 48.1Aa & 37.1ABa & $28.4 \mathrm{Ba}$ & 37.9 \\
\hline Mean & 29.0 & 28.6 & 23.9 & \\
\hline V.C. (\%) & \multicolumn{4}{|c|}{17.66} \\
\hline
\end{tabular}

Equivalent upper or lower case letters in rows and columns, respectively, do not differ statistically by the Tukey test $(p<0.05)$.

The sodium (Na) content and the soil percentage of exchangeable sodium (PES) evaluated before and after the Green manure cultivation, evidenced effects without interaction among the treatments. Analyzing the average values founded in the green manures in all water sources, it is possible to verify that, both after and before; $\mathrm{Na}$ and PES presented higher values in AE and ANE, compared to TW (Table 7). Comparing the $\mathrm{Na}$ content before and after the Green manure cultivation, it is possible to verify that there was no statistical difference while analyzing each water source separately. Regarding the PES, there was a reduction for AE (from 8.10 to $6.75 \%$ ) and for ANE (9.15 para $7.55 \%)$. As the values of sodium did not differ before and after cultivation, it is assumed that the PES variation occurred due to the increase of the cation exchange capacity (CEC) of the soil after cultivation of the green manure (Table 6). For TW, ANE and AE the values of CEC before the cultivation were 45.5, 51.5 and $50.8 \mathrm{mmol}_{\mathrm{c}} \mathrm{dm}^{-3}$ (Table 2). After the cultivation, the values were 52.9, 61.1 and $61.7 \mathrm{mmol}_{\mathrm{c}} \mathrm{dm}^{-3}$ for TW, ANE and AE respectively, considering the average value obtained for all green manure. Santos et al. (2014), after the cultivation of Atriplex nummularia in saline-sodic soil, observed increase of $\mathrm{Ca}^{2+}$ and $\mathrm{Mg}^{2+}$ in the soil, raising the CEC. 
The soil $\mathrm{pH}$, after the Green manure cultivation, independently of the forager, increased on average from 5.6 to 6.2. This fact is correlated to the decreased potential acidity $(\mathrm{H}+\mathrm{Al})$, from 20.7 mmolc $\mathrm{dm}^{-3}$ to 13.3 mmolc $\mathrm{dm}^{-3}$ after the green manure cultivation. The content of $\mathrm{Ca}$ and $\mathrm{Mg}$ increased after the green manure cultivation, which influenced in the sum of the bases (SB) and consequently in the CEC. According to Ambrosano et al. (2014) the organic acids liberated during the decomposition act by lowering the potential acidity, which assists in the nutrients availability, as is the case of $\mathrm{Ca}$ and $\mathrm{Mg}$.

TABLE 7. Sodium (Na) and exchangeable sodium percentage (ESP) before and after cultivation with green manures (Calopo, Pigeon pea, Millet) cultivated in succession to irrigation with different water sources (tap water - TW, anaerobic effluent - ANE, aerobic effluent - AE). University of São Paulo, Animal Science and Food Engineering, 2014.

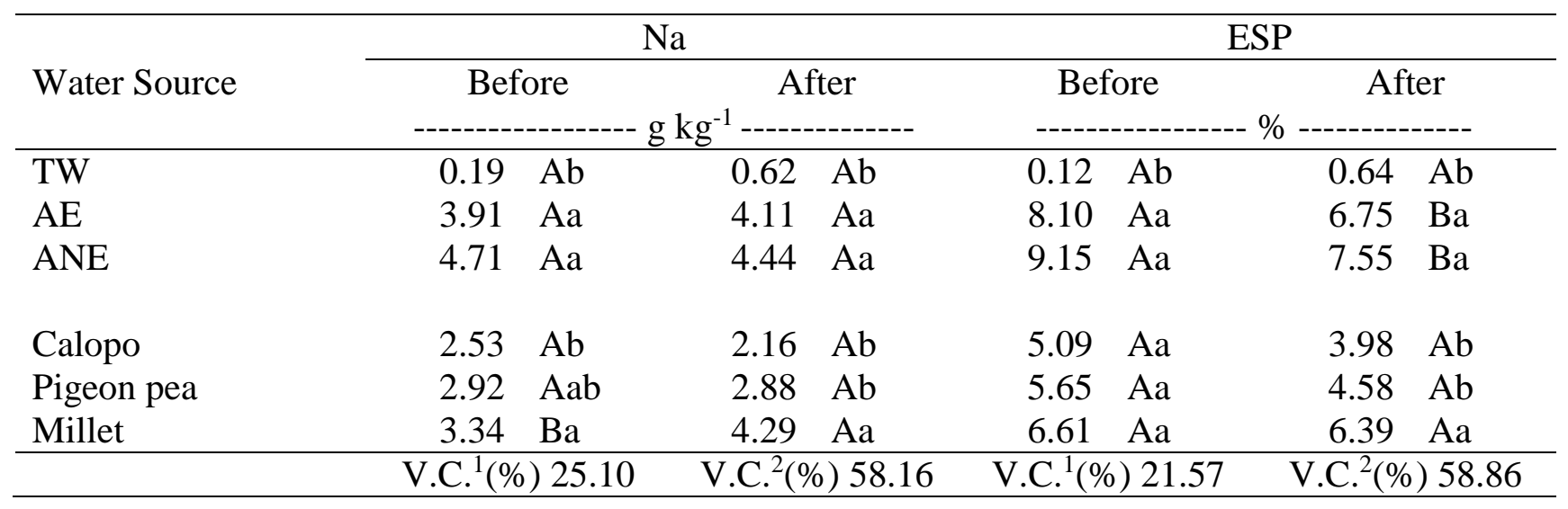

TW - Tap water ANE - anaerobic effluent, AE - aerobic effluent.

${ }^{1}$ Water Source, ${ }^{2}$ Period. Equivalent upper or lower case letters in rows and columns, respectively, do not differ statistically by the Tukey test $(\mathrm{p}<0.05)$

After analyzing the mean of the water sources in the treatments of the green manures, it is possible to verify that the $\mathrm{Na}$ only varied after the Millet cultivation, because before it presented the value $3.34 \mathrm{~g} \mathrm{~kg}^{-1}$ and then the value determined was $4.29 \mathrm{~g} \mathrm{~kg}^{-1}$ (Table 7). This occurred probably by the recycling of the sodium that was in the deepest layer of the soil in the experimental plot. ESP was not influenced by forage cultivation. Rossi et al., (2014) also did not obtain an ESP reduction after cultivation with millet in irrigated soil with dairy effluent. It should be pointed out that, when analyzing the levels of $\mathrm{Na}$ before the cultivation of green manure (Table 7), the plots that were to be cultivated with millet had, on average, $3.34 \mathrm{~g} \mathrm{~kg}^{-1} \mathrm{Na}$, differing statistically from the plots that would be cultivated with Calopo, which had on average $2.53 \mathrm{~g} \mathrm{~kg}^{-1} \mathrm{Na}$. The plots that were to be cultivated with dwarf pigeon had an intermediate value $\left(2.92 \mathrm{~g} \mathrm{~kg}^{-1}\right)$, without statistical difference of the other treatments. Although millet cultivation, in the mean of treatments with water sources, did not result in a decrease in soil PST (before $6.61 \%$ and then $6.39 \%$ ), even with an increase in Na content, this was the plant that most absorbed sodium (Figure 1). Jesus et al. (2015) explain two mechanisms of phytoremediation of saline soils: the first would be the reduction of $\mathrm{pH}$ by root exudates of plants, which would allow the increase of $\mathrm{CaCO}_{3}$ dissolution, with the availability of $\mathrm{Ca}^{2+}$, which would change with sodium in the CEC of the soil and would allow leaching; Second would be the absorption of sodium by the plant and incorporation in its phytomass, that is, phytoextraction (Nouri et al., 2017).

\section{CONCLUSIONS}

Millet presented the highest productivity in relation to the other green manures, except for the cultivation after the irrigation of the soil with anaerobic effluent.

Phytoextraction of nitrogen $(\mathrm{N})$, calcium $(\mathrm{Ca})$, magnesium $(\mathrm{Mg})$ and sulfur $(\mathrm{S})$ was similar for all green manures in water sources. The potassium $(\mathrm{K})$, independent of the water source, was 
phytoextracted in greater quantity by the Millet. Calopo phytoextract increased phosphorus (P) when cultivated in soil irrigated with aerobic and anaerobic effluents.

Millet was the most efficient phytoextracting sodium species, followed by Calopo. However, no green manure was effective in phytoremediation of the soil, because the exchangeable sodium percentage (ESP) was not satisfactorily reduced, and no further effluent contribution to the studied soil was advisable.

\section{ACKNOWLEDGEMENTS}

The authors thank FAPESP - Fundação de Amparo a Pesquisa do Estado de São Paulo, for their support in the development of this research (FAPESP Support $n^{\circ} 2012$ / 19239-0) and Capes for granting the master's fellowship to the first author.

\section{REFERENCES}

Ambrosano EJ, Rossi F, Guirado N, Mendes PCD (2014) Adubação verde na agricultura orgânica. In: Adubação verde e plantas de cobertura no Brasil: fundamentos e prática. Brasília, Embrapa, p45-80.

Ayers RS, Westcot DW (1999) A qualidade da água na agricultura. Tradução de Gheyi HR, Medeiros JF, Damasceno FAV. Campina Grande, UFPB. 218p.

Azzolini JC, Fabro LF (2013) Monitoramento da eficiência do sistema de tratamento de efluentes de um laticínio da região meio-oeste de Santa Catarina. Unoesc \& Ciência - ACET 4(1):43-60.

Brasil. Resolução No 357, 17 de março de 2005. Dispõe sobre a classificação dos corpos de água e diretrizes ambientais para o seu enquadramento, bem como estabelece as condições e padrões de lançamento de efluentes, e dá outras providências na Resolução CONAMA no 357, de 17 de março de 2005. Disponível em: http://www.mma.gov.br/port/conama/res/res05/res35705. Acesso em: $14 / 06 / 2017$.

Calegari A, Carlos JAD (2014) Recomendações de plantio e informações gerais sobre o uso de espécies para adubação verde no Brasil. In: Lima Filho OF et al. Adubação verde e plantas de cobertura no Brasil. Brasília, Embrapa, 507p.

CETESB - Companhia de Tecnologia de Saneamento Ambiental (2006). Orientação para apresentação de projeto visando à aplicação de água de reuso proveniente de estação de tratamento de esgoto doméstico na agricultura. CETESB, 11p.

EMBRAPA. Centro Nacional de Pesquisa de Solos (1997) Manual de métodos de análise de solos. 2 ed. Embrapa, 212p.

Farias JRB, Bergamaschi H, Martins SR (1994) Evapotranspiração no interior de estufas plásticas. Revista Brasileira de Agrometeorologia 2:17-22.

Ferreira DF (2011) Sisvar: a computer statistical analysis system. Ciência e Agrotecnologia 35(6):1039-1042.

FAO - Food and Agriculture Organization of the United Nations (2008) Land resources, management, planning and use. Available: http://www.fao.org/ag/agl/agll/spush. Accessed: Sep 20, 2014.

Gomes TM, Rossi F, Tommaso G, Ribeiro R, Macan NPF, Pereira RS (2015) Treated dairy wastewater effect on the yield and quality of drip irrigated table beet. Applied Engineering in Agriculture 31(2):255-260. DOI: http://dx.doi.org/10.13031/aea.31.11002

Jesus JM, Danko AS, Fiúza A, Borges MT (2015) Phytoremediation of salt-affected soils: a review of processes, applicability, and the impact of climate change. Environmental Science and Pollution Research 22(9):6511-6525. DOI: http://dx.doi.org/10.1007/s11356-015-4205-4

Koppen W (1931) Grundriss Der Klimakunde. Water de Gruyter, 390p. 
Malavolta E, Vitti GC, Oliveira AS (1997) Avaliação do estado nutricional das plantas: princípios e aplicações. 2 ed. Potafos, 319p.

Mendonça HV, Ribeiro CBM, Borges AC, Bastos RR (2015) Sistemas alagados construídos em batelada: remoção da demanda bioquímica de oxigênio e regulação do $\mathrm{pH}$ no tratamento de efluentes de laticínios. Revista Ambiente Água 10(2):442-453.

Nouri H, Borujeni SC, Nirola R, Hassanli A, Beecham S, Alaghmand S, Saint C, Mulcahy D (2017) Application of green remediation on soil salinity treatment: a review on halophytoremediation. Process Safety and Environmental Protection 107:94-107. DOI: http://dx.doi.org/10.1016/j.psep.2017.01.021

Prados, NC (1986) Contribución al estudio de los cultivos enarenados en Almeria: necessidades hídricas y extración del nutrientes del cultivo de tomate de crescimneto indeterminado en abrigo de polietileno. 1986. 195f. Tese (Doutorado em Fitotecnia) - Cajá Rural Principal, Almeria.

Raij B van et al. (2001) Análise química para avaliação da fertilidade de solos tropicais. Instituto Agronômico, 285p.

Rossi F, Gomes TM, Tol JCHB, Ferraz MR, Luz PHC, Ambrosano EJ (2014) Fitoextração de sódio pelo cultivo do milheto em sucessão a produção da beterraba irrigada com águas residuárias de origem agroindustrial. Cadernos de Agroecologia 9(4):1-11.

Santos RA, Carneiro PT, Santos VR, Costa LC, Santos CG, Neto ASS (2014) Crescimento de leguminosas utilizadas na adubação verde em diferentes níveis de sais na água de irrigação. Revista Brasileira de Engenharia Agrícola e Ambiental 18(12):1255-1261. DOI:

http://dx.doi.org/10.1590/1807-1929/agriambi.v18n12p1255-1261

Sutar AS, Mulla RK, Ranveer AC (2015) Effluent treatment plant of dairy wastewater: a performance evaluation. International Research Journal of Engineering and Technology 2(8):837840. 